Article

\title{
Economic Analysis of Climate Change Best Management Practices in Vermont Agriculture
}

\author{
Alexander P. Helling ${ }^{1, *}$, David S. Conner ${ }^{1}$, Sarah N. Heiss ${ }^{1}$ and Linda S. Berlin ${ }^{2}$ \\ 1 Department of Community Development and Applied Economics, University of Vermont, 146 \\ University Place, Burlington, VT 05405, USA; E-Mails: 97dconne@uvm.edu (D.S.C.); \\ sarah.heiss@uvm.edu (S.N.H.) \\ 2 Department of Nutrition and Food Sciences, University of Vermont, 105 Carrigan Drive, \\ Burlington, VT 05405, USA; E-Mail: linda.berlin@uvm.edu \\ * Author to whom correspondence should be addressed; E-Mail: ahelling@uvm.edu; \\ Tel.: +1-651-315-6108.
}

Academic Editor: Stephen J. Herbert

Received: 30 April 2015 / Accepted: 15 September 2015 / Published: 18 September 2015

\begin{abstract}
Climate change impacts local agricultural systems in detectable and distinguishable ways from large-scale shifts in water, land, and weather patterns to regionally specific distributions of weeds, pests, and diseases. Best management practices for adapting to and mitigating the effects of climate change include modifications to farm production through adjusted intensity and product types and changing land use through crop siting and tillage practices. Farmer perceptions of risk and profitability of best management practices are key determinants of adoption, which traditional incentive programs like the Environmental Quality Incentive Program attempt to address by providing financial and technical support. To ensure that payments offered through these programs that maximize adoption, regional incentive payments must be based upon locally established costs. This paper focuses on the cost of implementing and maintaining climate change specific best management practices (CCBMPs) for twelve diverse farms in Vermont. Specifically, three CCBMPs for Vermont are examined: cover cropping, management intensive rotational grazing (MIRG), and riparian buffer strips. Results show the average cost for cover cropping is $\$ 129.24$ acre, MIRG is $\$ 79.82 /$ acre, and a tree based riparian buffer strip cost $\$ 807.33 /$ acre. We conclude that existing incentive payments for cover cropping and MIRG are below costs, likely resulting in under-adoption.
\end{abstract}


Keywords: agriculture; climate change; best management practices; adaptation; mitigation; economic analysis

\section{Introduction}

In its fifth report of the state of global climate change the Intergovernmental Panel on Climate Change [1-3] said that the impacts of climate change are now being felt by natural and human systems across the planet. On the global scale, climate change is having and will increasingly have an impact on biodiversity, hydrology, terrestrial ecosystems, human livelihoods, and food production [1-3]. Climate change projection models of agriculture in the United States predict both negative and positive impacts in the next 50 years, with direct impacts to agricultural operations resulting from changes to land, water, temperature, atmospheric $\mathrm{CO}_{2}$, and weather patterns [4]. These changes will be accompanied by broader and more complex economic variability and uncertainty in both local and global markets [5-7]. Furthermore, plant and animal production systems will experience variable effects from climate change [8-10].

This paper explores climatic impacts within the Northeastern United States, farmer adoption of practices to externally mitigate and internally adapt to these impacts, and costs associated with these practices compared with financial incentive payments through programs like the Environmental Quality Incentives Program (EQIP). This research will inform incentive payment programs from locally derived Best Management Practices (BMPs) costs to increase adoption by the farming community. Research utilizing direct from farmer, daily data collection for Climate Change Best Management Practice (CCBMP) costs in the Northeastern United States has not been conducted previously.

\subsection{Agricultural Impacts from Climate Change}

Climate change will result in a range of impacts for agriculture in the United States. Plants will exhibit variations in growth and yield due to higher temperatures, variable precipitation amounts, intensity, and frequency, and higher concentrations of atmospheric $\mathrm{CO}_{2}$ [9]. Higher temperatures, increases in consecutive dry days, and increases in hot nights have been found to reduce the yield and quality of crops [10]. Changes in precipitation patterns will result in varied consequences based on prior climate variables such as base rainfall amounts and soil characteristics, but more frequent and intense flooding and droughts are both likely [9]. Changes in soil erosion rates will also vary in response to changes in precipitation with areas experiencing significant rainfall increases likely to experience increases in soil erosion, and areas experiencing decreasing rainfall amounts likely to experience either increases or decreases in erosion due to changes in biomass production [11].

Agriculture will also experience changes as a direct consequence of changing $\mathrm{CO}_{2}$ levels. Increases in atmospheric $\mathrm{CO}_{2}$ have been show to typically result in an increase in plant photosynthesis and reduced water transpiration and usage in controlled experiments $[12,13]$. However, these changes also tend to decrease the longer the plant is exposed to increased levels of $\mathrm{CO}_{2}[6,12]$. Increased $\mathrm{CO}_{2}$ fertilization effect may provide benefits for growth rates, but interactions with other direct factors such 
as water availability and nutrient variations may counter some of these increases [13]. In addition, the Third National Climate Assessment in the United States [10] stated that these increases in photosynthesis may be further offset by a reduction in solar radiation from greenhouse gas increases. Increased tropospheric ozone also leads to photosynthesis suppression and lower yields, further impacting potential yield increases from increased levels of atmospheric $\mathrm{CO}_{2}$ [14]. Some researchers also call into question the $\mathrm{CO}_{2}$ fertilization impact under real world conditions, and further found that the potential benefits from elevated $\mathrm{CO}_{2}$ may not fully offset losses due to climate change $[15,16]$. However, the $\mathrm{CO}_{2}$ fertilization effect should not be discounted in discussions regarding climate change impacts on agriculture. If agricultural systems were to see increases in crop yields due to rising $\mathrm{CO}_{2}$ levels, there would be local, national, and global implications. This issue should be closely monitored in future CCBMP research for further developments.

Parallel to these plant related climate impacts, animals will experience additional effects. Rötter and Van de Geijn identified four categories in which climate change will impact animal agriculture: (1) livestock feedgrain availability and price; (2) livestock pastures and forage crop production and quality; (3) weather and extreme events on animal health, growth and reproduction; and (4) livestock diseases and pests [6]. Specifically, animal heat stress increases with increasing numbers of hotter days and nights, resulting in reduced reproduction and production of not only milk and meat, but eggs as well $[6,10,17]$. Additionally, while pasture productivity may increase due to a longer growing season and enhanced atmospheric $\mathrm{CO}_{2}$ fertilization effects [18], these increases are likely to be counteracted by decreased pasture productivity from increased weed pressure [19], losses due to heat stress [20], and increased operational costs from global market impacts [7]. Variable warming along with changing rainfall distribution may also modify the distribution of animal diseases that are sensitive to moisture and temperature levels, leading to increases in diseases such as mastitis [21].

These direct plant and animal impacts will also be accompanied by increased economic variability. The results of research regarding the economic impacts on United States and global agriculture from climate change are mixed depending on climate change projection models, inclusion and/or amount of yield changes from $\mathrm{CO}_{2}$ fertilization effects, water usage, and general modeling methods [8]. Adams further concluded that the economic impact on agriculture in the United States would be limited due to the globalized nature of the market based agricultural system. If United States crop production decreases, other countries would likely increase production to fulfill the existing demand hole the loss of United States crops left [8]. In other words, supply would rise in other countries to fill the gap left in the United States production. However, once again some studies [15,16] question the real world benefits of $\mathrm{CO}_{2}$ fertilization, and call into question the results of earlier economic impact studies. Calzadilla [22] found that global food production and GDP will fall as a result of climate change. In the United States, the economic impacts of climate change on agriculture have been projected to likely be negative [23]. Additionally, Malcom [5] found that while impacts could range from estimated increase in net returns of $\$ 3.6$ billion to a decrease in $\$ 1.5$ billion per year based on different climate change scenarios, the inclusion of the spread and redistribution of pests further reduced net returns by $\$ 1.5$ billion to $\$ 3.0$ billion. Projected increases in agricultural land use as a response to climate change have also been shown to result in increased negative impacts on environmental resources, including increased nitrogen runoff, soil erosion, and land use conversion [5]. 
Vermont will experience these global and national variations in $\mathrm{CO}_{2}$ fertilization rates, elevated tropospheric ozone, increased extreme weather events, and generally increased global temperatures [12]. However, local areas will also experience regionally specific impacts [5] such as an increasing length of the growing season and modified pest distributions. Hayhoe [18] predicted that the growing season in the northeastern United States will extend by nearly one month by the year 2100 due to an extended frost-free period. A changing climate also enables invasive species to expand their ranges and move into new regions; specifically, kudzu (Pueraria lobata) and privet (Ligustrum sinense; L vulgare) will be able to reach into the New England states by 2100 [24].

The local impacts Vermont will experience will be at least partially determined by its specific climatic, geological, and topographic characteristics. Climatically, Vermont has the classification of Continental Moist, and it experiences mild summers with temperatures between $70{ }^{\circ} \mathrm{F}-80{ }^{\circ} \mathrm{F}$, rarely exceeding $90^{\circ} \mathrm{F}$, but with high humidity. Winters are cold, and precipitation is moderate for all seasons, with growing seasons often experiencing large amount of rain [25]. Vermont's soil tends to be loamy, formed in glacial till. In addition, most of the landscape is that of sloping hills, with several larger rivers. Crop agriculture has historically been based on the flatter areas nearby these rivers. The sloping hills have historically been grazed with sheep and other livestock [26].

The USDA Census of Agriculture reported that Vermont had 7338 farms as of 2012, with a combined market value of agricultural products sold of over $\$ 776$ million on 1,251,713 acres, with the dairy industry accounting for approximately $73 \%$ of sales [27]. Furthermore, over 10,500 people are employed in agricultural processes in Vermont [28]. The recent devastation Vermont experienced as a result of Hurricane Irene [29], changing seasonal weather patterns [18], variable future economic conditions [5], changing disease and pest distributions [6,24], and more frequent and intense flooding [9] demonstrate that the long term health and viability of this important industry is threatened by a changing climate. While it is still somewhat unclear if hurricanes are increasing in intensity and frequency as a result of climate change [30], incidents like Hurricane Irene will likely be exacerbated by these additional impacts. The 2014 report Considering Vermont's Future in a Changing Climate: The First Vermont Climate Assessment concluded that it is "essential that Vermont agricultural enterprises develop forward-looking adaptation plans," in response to additional impending climatic changes [31].

\subsection{Responding to Climate Change}

Climate change impacts such as changing seasonal weather patterns [18], variable future economic conditions [5], changing disease and pest distributions [6,24], and more frequent and intense flooding [9] highlight a daunting list of present and future agriculture threats and potential vulnerabilities. In response to these challenges, various agricultural practices can be employed that offer both internal and external benefits. External benefits, or public benefits that occur off-site from the farm, are those that society broadly experiences as a result of on-farm practice changes. These external benefits would broadly be associated with climate change mitigation, and would consist primarily of greenhouse gas emission reductions, but could also include benefits such as improved water quality. Internal benefits, also thought of as private or on-site benefits, generally consist of improvements at the farm deploying the practice. In the context of climate change, internal benefits would most closely be associated with 
climate adaptation and could include enhancements in soil quality, reduced nutrient runoff, or increased environmental or economic resilience.

Fortunately, research concerning mitigation strategies to address climate change has increased dramatically over the past several decades. Mitigation strategies for responding to climate change have been divided into three categories: reducing emissions of $\mathrm{CO}_{2}, \mathrm{CH}_{4}$, and $\mathrm{N}_{2} \mathrm{O}$, enhancing removal of atmospheric $\mathrm{CO}_{2}$, and avoiding or displacing emissions [32]. The potential impact of these actions is huge given that agricultural land accounts for $37 \%$ of the Earth's surface, and agriculture produces $52 \%$ of methane and $84 \%$ of nitrous oxide emissions globally [32]. In a study based on U.S. crop averages that looked at converting conventional agricultural to alternative practices, it was found that no-till management reduces $\mathrm{CO}_{2}$ emissions from 168 to $137 \mathrm{~kg} \mathrm{C} \mathrm{ha}^{-1}$ per year and also increases the levels of soil carbon sequestration [33]. Additional research shows that sustainable management of soils and water resources, through sustainable practices such as cover cropping and nutrient cycling through use of compost and manure, has the potential to offset annual $\mathrm{CO}_{2}$ emissions by one-fourth to one-third [34]. Given that adequate technology and best management practices already exist, and that specific agricultural practices have such a potential to reduce or sequester greenhouse gas emissions, CCBMPs for climate change mitigation can and should be implemented immediately $[32,35]$.

While mitigation strategies aim to provide external benefits that minimize the extent of climate change itself, adaptation strategies are responses or adjustments to the increased internal risks posed to the farm itself by climate change. Vermont farmers are unlikely to experience any internal benefits from reductions in $\mathrm{CO}_{2}$ emissions if emission continue to rise from other sources; therefore, it will be necessary to adapt to the forecast changes. Smit [36] categorized potential climate change adaptation practices as farm production through modified intensity and product types, land use through crop siting and tillage practices, land topography for manipulating moisture levels, irrigation strategies, and operational timing. The Intergovernmental Panel on Climate Change's 2014 report on climate change gives similar recommendations with an emphasis on cropland management, grazing land management, and restoration of organic matter in soils [1,3]. Dunnington [28] also identifies crop diversity and research as the ways forward for Vermont's climate adaptation. These identified strategies are clearly quite broad in scope and there are abundant BMPs within each category that agricultural can employ in the service of climate adaptation. These changes will often be incremental modifications to existing production systems, and will not always be sufficient to adapt to the more extreme climate change scenario impacts. Regardless, the adoption of these practices, even in the absence of climate change, is advisable given their other potential benefits.

Traditional farm BMPs, those positively tested and proven approaches for farm production and management, are broad in scope and have been shown to result in a wide range of internal farm improvements such as enhanced soil quality, increased vegetative cover, reduced erosion, cleaner water, increased economic viability, and generally reduced farm risk. These practices also have the potential to help farmers adapt to climate change and reduce atmospheric carbon dioxide levels $[34,37]$. The best practices for climate change that also serve more traditional farm needs vary from region to region, and must be determined based upon local conditions [32]. Locally relevant CCBMPs in Vermont include cover crops, riparian buffer strips, and management intensive rotational grazing (MIRG) [37]. Following identification of relevant CCBMPs in Vermont, it is necessary to understand the factors that will influence actual adoption of these practices. The regional and local 
variability of CCBMP costs and the necessity of incentive programs offering payments that maximize practice adoption necessitated that this study investigate the following research question: What is the cost to install, maintain, remove and/or incorporate CCBMPs in Vermont over the course of one growing season?

\section{Selected Literature}

A 2012 study by the USDA Economic Research Service [5] reported that many challenges associated with climate change will vary from region to region and adaptation measures must be tailored to local conditions. The necessary changes, such as CCBMPs, utilized in response to these challenges may in fact be the largest concern for United States agriculture moving forward [35].

Resistance to changing farm production practices solely in response to climate impacts may be a roadblock to adoption. One study found only $20 \%$ of farmers that experienced climatic variations consciously modified their farm operations [38]. Wall [39] stated that farmers will likely not adopt practices purely due to their climate implications, but for other risk management, environmental, and economic reasons. Widespread adoption of CCBMPs will therefore require that the practices provide not only the internal benefits of climate change risk adaptation, but more traditional economic risk management such as environmental improvements and economic profitability. This paper focuses on three key CCBMPs for Vermont that may provide both mitigation and adaptation benefits: cover cropping, MIRG, and riparian buffer strips.

\subsection{Cover Crops}

Cover cropping is one of the more common practices in use in Vermont and provides both traditional BMP benefits as well as additional internal and external climate effects. The Vermont Natural Resources Conservation Service [40] defined cover crops as "crops including close growing grasses, legumes, and forbs for seasonal cover and other conservation purposes." Internal benefits provided to farms that use cover crops include reduced erosion, increased soil organic matter, captured and recycled nutrients in the soil, increased biodiversity, suppressed weeds, managed soil moisture, and minimized and reduced soil compaction [40,41]. Utilizing legume cover crops also promotes biological nutrient fixation that reduced energy use and decreases reliance on greenhouse gas (GhG) intensive nitrogen fertilizers by fixing nitrogen throughout the plant's life cycle [32]. While the farmer may experience the internal benefits of decreased fuel and nitrogen costs, the public would also receive external benefits through decreased greenhouse gas emission that work to mitigate climate change. Morton's study [42] on the economics of cover crop biomass found that including cover crops in cropping systems has both direct and indirect economic costs and benefits that will vary based upon farm operations and characteristics. Costs to establish and maintain cover crops include inputs of seeds, and labor of ground preparation, planting, mowing or discing, and incorporation [43].

A Purdue University study estimated a cover crop cost per acre for Indiana in 1982 was \$33-\$39 per acre, or \$79.92-\$94.45 in 2015 dollars [44]. A study in California estimated the cost at $\$ 90-\$ 170$ per acre [43]. Cover cropping costs for larger scale corn and soybean operations tend to fall in the $\$ 30-\$ 50$ range [45]. Variations within the study likely results from differences between farm operations. A study on Vermont farmers' Willingness-to-Accept (WTA) payments for cover crops 
found farmers accepted an average of $\$ 125.16$ per acre [46]. The Sustainable Agriculture Research and Education (SARE) study [45] also found that incentive payments can be an important catalyst to cover crop adoption for some farmers, but additional motivation comes from the readily apparent benefits.

\subsection{Management Intensive Rotational Grazing}

Management-intensive rotational grazing, planned rotational grazing, or simply rotational grazing, is "any grazing method that utilizes repeating periods of grazing and rest among two or more paddocks or pastures [47]." MIRG has internal advantages of wasting less forage by the animals leading to increased stocking density, decreased hay requirements, better animal temperament, and heightened farmer awareness of and ability to detect diseases or other problems, improved nutrient distribution, and greater environmental stewardship [47]. Intensively managed pastures, based on the intensity, animal numbers, and frequency of their grazing, can also provide external mitigation benefits by sequestering carbon [48]. A summary of the research on the social implications of MIRG in Wisconsin found that grazing operations are typically profitable and often provide higher profits per cow than confinement operations [49]. Additionally, a 2007 project studying Northeastern US dairy farmers that utilize rotational grazing reported higher levels of farming satisfaction, reduced stress, financial progress and improved herd health [50]. The same study also reported that income, land, and labor required were the most common barriers to adoption for farmers.

Economic costs to raise animals through incorporation of MIRG are traditionally calculated as cost per animal to produce milk or meat. This study is specifically interested in the cost per acre of the MIRG practice itself, as the climate benefits from MIRG are conferred on a per acre basis as opposed to per animal. In addition, our study seeks to understand the specific costs associated with implementing and maintaining MIRG as a practice, as opposed to the comprehensive cost for a product. As a result, our MIRG as a CCBMP findings are at a different scale from typical enterprise budgets for MIRG production systems. Little research exists that documents either the cost of implementing the practice of MIRG itself or farmers' WTA levels.

\subsection{Riparian Buffer Strip}

The third BMP we will evaluate is the buffer strip. A Riparian buffer strip, also called vegetative filter strip [51], or riparian forest buffer, is an "area of trees and shrubs located adjacent to streams, lakes, ponds, and wetlands [52]." The Natural Resources Conservation Service (NRCS) contends that these buffer strips help keep sediment, nutrients, agricultural inputs, and other pollutants from entering water bodies and reduce nutrients in shallow subsurface water flows. In addition, they provide food and habitat for wildlife, lower local water temperatures, slow flood flows, reduce erosion, and produce economic timber or wood fiber products. Increasing vegetation in previously degraded areas can also increase carbon storage. Generally, these benefits would be experienced by the public as a whole, but the farmer would also likely experience improvements, especially on farm perimeters.

Costs to establish and maintain a conservation, or forest buffer strip vary greatly depending upon size, density, and type of buffer. A 2000 study in Maryland found the costs range from \$218-\$729 per acre [53], with grass buffers tending to cost less than tree variations. Additionally, a Pennsylvania Department of Environmental Protection riparian forest buffer guide found an even broader range of 
\$385-\$4,723 per acre, including labor, with density of tree plantings being the greater driver of variability [54]. Given these large ranges, local numbers are needed to accurately assess potential costs. A study on farmers WTA levels for buffer strips found an average of $\$ 168.33$ per acre [46]. However, this estimate appears to be centered upon grass based buffer strips, as opposed to tree based.

\subsection{Farmer Adoption}

Perceptions of MIRG, cover cropping, riparian buffer strips, and other CCBMPs along with the adoption of best management practices in general are influenced by demographics, environmental awareness and concern, income and wealth, farm characteristics, agricultural extension support, and available information [55,56]. Within extension support and information, a 2013-2014 study on the effectiveness of various cover crop educational opportunities found that self-experimentation, local workshops, and internet research were the most effective means of learning about new cover cropping methods [45].

A meta-analysis of farmer best management practices adoption literature found that information, financial, and networking variables were most capable of predicting best management practice adoption [55,56]. In Vermont, incentive levels were found to significantly impact farmer decision-making regarding BMPs [46].

Perceptions of risk and profitability are also important to BMP adoption as perceived risk is related to the perceived profitability of a BMP [57-59]. If there is a perceived risk that implementing a best management practice will threaten the viability of a farm, this will typically outweigh the perceived benefits of implementing that practice regardless of environmental awareness and other factors [57]. Understanding the costs of CCBMPs is necessary given the importance financial considerations play in their adoption, as well as the reality that a majority of farmers have net negative incomes [60,61]. Specifically, the USDA Economic Research Service notes that many farms are not even profitable in the best farm income years, and the projected median farm income is $-\$ 1,558$ in 2015 , relatively unchanged from 2014 when the number was $-\$ 1,570$ [61]. While limited enterprise budgets may exist for farm best management practices and general crop production, they may often be "rule-of-thumbed" by academic experts utilizing average costs and profits, potentially resulting in dangerously misleading estimations of total budgets and unnecessarily increased economic risk [62]. As a result, more locally specific studies are needed to determine accurate costs for establishing these practices to ensure revenues cover costs and economic risks can be adequately addressed [37]. Dunnington also identifies additional research in Vermont aimed at reducing the cost and risks for farmers in experimenting with new production practices as important for Vermont' agricultural future [28].

Federal programs exist, such as EQIP and the Conservation Stewardship Program (CSP), that attempt to address these economic barriers to adoption of BMPs, by incentivizing BMPs through financial and technical assistance. While these programs were not designed to include climate change adaptation and mitigation, the practices they promote often provide additional internal and external climate benefits. Hypothetically, these programs pay farmers for BMP adoption at the point where a farmer's willingness to accept (WTA) equals the government or public's willingness to pay (WTP) [63]. WTA and WTP levels vary from farmer to farmer and must be regionally assessed to ensure cost effectiveness for both farmers and the government. WTA levels for CCBMPs in the 
Northeast have been established at a very limited scale, with a recent one year study finding farmer WTA level of $\$ 125.16$ per acre for cover cropping and $\$ 168.33$ per acre for buffer strips [46]. The corresponding WTP levels are demonstrated through the payment levels provided through programs such as EQIP and CSP.

This research will improve regional incentive payment programs, specifically EQIP, by providing more accurate local data to inform payment levels. By comparing costs found in this study to existing EQIP payment levels, we can assess if current payment levels are high enough to properly offset practice costs to a degree that removes the economic risks faced by the farm. WTP levels can then be compared to WTA levels to assess if payment levels are high enough to maximize practice adoption, as adoption should be maximized when WTP equals WTA. In addition, CCBMP cost data will give farmers concrete financial figures to incorporate into risk and profitability calculations, which are vital considerations in practice adoption. The costs established in our study will also be directly supplied to farmers considering implementing these programs, as understanding the establishment and maintenance costs will reduce economic uncertainty moving forward.

The regional and local variability of CCBMP costs and the necessity of incentive programs offering payments that maximize practice adoption necessitated that this study investigate the following research question: What is the cost to install, maintain, remove and/or incorporate CCBMPs in Vermont over the course of one growing season? It should be noted that while this is an economic based study, the cost of CCBMPs discussed here is more of an accounting cost than a pure economic assessment as indirect impacts to farmer yields and profit such as opportunity costs are not considered.

\section{Methods}

This analysis is part of the Vermont Agricultural Resilience in a Changing Climate (VARCC) research initiative, a transdisciplinary and participatory action research based initiative that aims to identify BMPs that will help farmers adapt to the impacts of climate change. The VARCC initiative functions through a diverse team of stakeholders including farmers, agricultural service providers, researchers and community organizations to address the impacts of climate change in Vermont by focusing on evaluating and implementing on-farm climate change mitigation and adaptation practices [37]. The VARCC research initiative was conceptually divided into four phases: 1. Initial investigation including literature review, stratified survey, and key informant interviews, 2. On-farm research concerning social, economic, agroecological, and map elements of the broader research study, 3. Farmer-to-farmer workshops, policy workshops, and farmer-service provider exchanges concerning CCBMP recommendations, and 4. Expansion to the Connecticut River Valley of Vermont replicating phases $1-3$.

\section{Farm Selection and Data Collection Process}

This study builds upon work done during phase 1 of the VARCC initiative during which the broader research team utilized survey and interview data, as well as experience, professional interest, and the expertise of the principal investigators, to identify twelve farm research participants and establish the CCBMPs of interest [37]. The twelve farms were selected due to their use or intended use of the selected CCBMPs, and included three each of vegetable, dairy, meat, or diversified producers. Nine of 
the twelve farms were utilizing the identified CCBMPs prior to the start of this study, while the remaining three were not. This resulted in a clearer picture of the differences in costs to establish $v s$. maintain the different practices. In other words, for nine of the farms, there was no change in practices regarding the utilization of CCBMPs as each farm already had the practices in place, while the 3 other farm were establishing the practices as essentially new operational components, and were as such not transitioning from a more conventional practice to another.

Institutional Review Board approval was obtained prior to engaging farmers for data collection. Sixty minute interviews were conducted with each selected farmer following farmer selection to verify consent to participate and contribute data, general study participation and establish a greater working knowledge of their CCBMP installation, maintenance and/or removal plans. Farmer input, farm enterprise budget literature, and economic theory were used to create custom data collection spreadsheets for each farm. Farmers were requested to utilize these data collection sheets to document daily labor, inputs such as soil amendments or seeds, and fuel costs along with associated activities and equipment used. Additionally, data were focused exclusively on costs of activities, materials and equipment used for the installation, maintenance, incorporation, or removal of assigned CCBMPs. Cost data were split into two categories when applicable: establishment costs, and maintenance costs. This allowed for variation in the farm's status for each CCBMP, as some farms were in the process of establishing the practices while some were maintaining already established practices. Each farm was requested to track either cover crop, MIRG, or riparian buffer strip costs, and three farms agreed to track multiple CCBMPs.

These data were to be returned to the researchers each month via email or mail based upon farmer preference. Data collection began with the start of each farm's respective growing season, typically April 1st, 2014, and lasted through the end of each farm's respective growing season, from October-December 2014. Participating farmers were compensated \$50 per hour for their time spent contributing to the data collection. Following completion of the growing season, each farm's data were aggregated for the entire growing season by farmer labor hours (including planning for the season), employee or other labor hours, farmer tractor hours, employee or other tractor hours, fuel used in gallons and type, equipment purchases, and other purchases such as seeds or lime.

Labor hours were translated to labor costs at a rate of $\$ 20 / \mathrm{h}$ for farmers, and $\$ 12 / \mathrm{h}$ for employees or other workers and aggregated. Inputs including fuel at a price of \$3.24/gallon for diesel and $\$ 2.50 /$ gallon for gasoline, were combined with total labor costs to compute a total CCBMP cost for one year of installation, maintenance, incorporation, and/or removal. Analysis was then done to establish cost per acre for each practice, categorized by producer type. Additional analysis consisted of determining average practice costs across producer categories, adjustments to the data to improve comparability by removing extra equipment costs, and general farm characteristic comparisons.

\section{Results and Discussion}

All twelve participating farms returned data in some form throughout the research period. Seven of the twelve farmers returned data with moderate consistency of at least once every two months, four returned all data at the end of the season, and one returned data twice throughout the season. Eleven of the twelve participating farms returned data of high enough quality and quantity for analysis, with the 
twelfth farm lacking enough detail on practice cost breakdowns. This resulted in the underrepresentation of the dairy producer category-two as opposed to the three in each other category-in data analysis. Data results are reported in Table 1. Total costs were divided between labor, split between the farmer and other which includes employees, friends, and family, and inputs.

Table 1. Annual Climate Change Best Management Practice Costs.

\begin{tabular}{|c|c|c|c|c|c|c|c|}
\hline Farm & $\begin{array}{c}\text { Total Labor } \\
\text { (Farmer/Other) (h) }\end{array}$ & Labor Costs (\$) & Input Costs (\$) & Total Cost (\$) & Area (Acres) & \$/Acre & $\begin{array}{c}\text { Adjusted } \\
\text { \$/acre } \\
\end{array}$ \\
\hline \multicolumn{8}{|c|}{ MIRG (Dairy Cattle) } \\
\hline Farm 3 & $350.00 / 33.40$ & 6586.00 & 3968.16 & 10554.16 & 127.00 & 83.10 & 83.10 \\
\hline Farm $1^{\mathrm{A}}$ & $122.00 / 72.00$ & $3,304.00$ & 178.97 & 3602.85 & 35.00 & 102.94 & 102.94 \\
\hline Farm $1^{\mathrm{B}}$ & $23.00 / 23.00$ & 736.00 & 431.91 & 1167.91 & 35.00 & 33.37 & 33.37 \\
\hline \multicolumn{8}{|c|}{ MIRG (Meat Cattle) } \\
\hline Farm 4 & $24.50 / 0.55$ & 623.60 & 452.80 & 1076.40 & 21.00 & 51.26 & 51.26 \\
\hline Farm 2a & $418.75 / 175.50$ & 10481.00 & 2052.88 & 12533.88 & 170.00 & 73.73 & 73.73 \\
\hline Farm $2 b$ & $446.20 / 180.50$ & 11090.00 & 2569.10 & 13659.10 & 170.00 & 80.35 & 80.35 \\
\hline Farm 2c & $456.70 / 180.50$ & 11300.00 & 2637.14 & 13937.14 & 170.00 & 81.98 & 81.98 \\
\hline \multicolumn{8}{|c|}{ MIRG (Meat Sheep) } \\
\hline Farm 5 & $25.45 / 0.00$ & 509.00 & 692.16 & 1201.16 & 60.00 & 20.02 & 20.02 \\
\hline \multicolumn{8}{|c|}{ Cover Crop (Vegetables) } \\
\hline Farm 6a & $7.16 / 38.40$ & 604.00 & 1377.88 & 1981.88 & 22 & 90.09 & 90.09 \\
\hline Farm 6b & $14.50 / 23.05$ & 566.60 & 1760.12 & 2326.72 & 12 & 193.89 & 193.89 \\
\hline Farm 6c & $21.66 / 61.45$ & 1170.60 & 3138.00 & 4308.60 & 34 & 126.72 & 126.72 \\
\hline Farm 9 & $2.00 / 15.00$ & 220.00 & 1589.60 & 1809.60 & 8.63 & 209.68 & 105.40 \\
\hline Farm 10 & $5.50 / 0.00$ & 110.00 & 102.48 & 212.48 & 0.25 & 849.92 & 849.92 \\
\hline \multicolumn{8}{|c|}{ Cover Crop (Diversified) } \\
\hline Farm 7 & $25.25 / 22.75$ & 778.00 & 994.00 & 1772.00 & 12.2 & 145.26 & 155.60 \\
\hline Farm $8^{\mathrm{A}}$ & $47.10 / 0.00$ & 942.00 & 499.6 & 1441.60 & 5.35 & 269.46 & 269.46 \\
\hline Farm $8^{\mathrm{B}}$ & $21.25 / 14.00$ & 593.00 & 1005.72 & 1598.72 & 5.35 & 298.83 & 298.83 \\
\hline \multicolumn{8}{|c|}{ Riparian Buffer Zone (Diversified) } \\
\hline Farm $11^{\mathrm{B}}$ & $16.00 / 26.00$ & 632.00 & 555.00 & 1211.00 & 1.5 & 807.33 & 807.33 \\
\hline
\end{tabular}

Notes: Farm 3 Farmer labor is all employees paid at a rate of $\$ 15 / \mathrm{h}$, and other includes work contracted out at a rate of $\$ 40 / \mathrm{h}$. Farm 2a does not include cover cropping and subsoiling. Farm $2 \mathrm{~b}$ includes cover cropping for 4.5 acres of total area, and Farm 2c includes both cover cropping on the 4.5acres and subsoiling on 1.5 acres of total area. Farm 6a was the portion of the acreage in production for the season, Farm $6 \mathrm{~b}$ is out of production for the season, and Farm $6 \mathrm{c}$ is the aggregation of both. ${ }^{\text {A }}$ denotes costs associated with regular maintenance activities for newly established CCBMPs; ${ }^{B}$ denotes costs associated with establishing a new CCBMP.

Five farms collected data on MIRG of total acreages between 21 and 170 acres. Four of these operations were already established prior to this season, and demonstrate snapshots of one season in already established operations. The fifth farm (Farm 1) recently changed hands, and represents a new operation as a large portion of their early season labor costs consisted of infrastructure, such as perimeter fencing installation. The established costs for the fifth farm are therefore of limited comparability to the first four, but is a useful picture of the year-one establishment costs for a MIRG 
operation. Table 1 shows that total yearly costs per acre for the MIRG were fairly consistent, ranging between $\$ 51.26$ to $\$ 81.98$ for beef cows with an average of $\$ 66.61$, and cost of $\$ 20.20$ for sheep. Dairy operations show slightly higher costs of $\$ 83.10$ and $\$ 102.94$, averaging $\$ 93.02$ per acre. The separate establishment cost associated with the new MIRG operation (Farm 1), were $\$ 33.37$ per acre. In total, Farm 1's establishment plus maintenance cost was $\$ 136.31$ per acre. Averaging the maintenance costs for all four beef and cow dairy MIRG operations (Farm 2a), we find an average cost per acre of \$79.82. Farm 2 also utilizes subsoiling and cover cropping within their MIRG operation. The costs associated with these practices were separated from the basic MIRG operations, as seen in Table 1. While outside the scope of this study, it should be noted there may also be costs associated with changes in yield when converting from convention confinement livestock to MIRG grazing production. These potential increases or decreases in yield would impact farm profitability alongside the associated changes in other capital and variable expenses.

Five farms collected cover cropping data on practice areas between 0.25 and 34 acres. Four of the cover cropping operations were also on established fields, with the fifth representing a new installation from pasture to cover crop (Farm 8). Similar to MIRG, the fifth cover cropping operation is of limited comparability to the other four, but does provide a picture into the establishment costs of a new cover cropping practice. Vegetable cover cropping operations generally ranged from $\$ 90.09$ to $\$ 209.68$ per acre yearly for established fields, with the smallest, Farm 10 which consisted of four 1/16 acre plantings, being the most costly at $\$ 849.92$ per acre.

Farm 9 purchased a grain drill during the season and was the only farm to purchase large equipment necessary for their CCBMP, removing that purchase reduced their maintenance cost per acre to $\$ 105.40$, comparable to the other established cover crop operations. Farm 7 did not report fuel usage, so the \$/acre in Table 1 is comparatively low. Given their tractor usage of $22.25 \mathrm{~h}$ for the season, and an average gallon/h factor of 1.75 for other similar farms, an extra $\$ 10.34$ per acre is warranted, for a final adjusted cost of $\$ 155.60$ /acre. These adjusted costs are shown in the far right column of Table 1 . Additionally, farm 6 tracked cover cropping both on in-production and out-of-production fields, these data are shown separately and combined in Table 1 . The newly established cover cropping operation at Farm 8 had a maintenance cost of $\$ 269.46$ per acre, and an establishment cost of $\$ 298.83$, and a combined cost of $\$ 568.29$ per acre. High establishment costs were driven primarily by a large number of farmer labor costs associated with establishing a new field, including rock and debris removal, and tractor work. Using the adjusted numbers for Farms 7 and 9, the combined data for Farm 6, and removing the two outliers of Farms 8 and 10, the average cover crop maintenance cost for an established practice was $\$ 129.24$ /acre. Note that Farms 8 and 10 were identified as outliers because Farm 8 is a newly established practice, and Farm 10's utilized a different field structure. The 0.25 acres reported on by Farm 10 were the aggregation of crop beds not necessarily in proximity to one another, as opposed to the other farms that reported on larger acreages that combine all crop beds into individual fields.

The final farm, farm 11, collected data on a newly established 1.5 acre riparian, tree-based buffer strip. All work was done by hand, so the number of labor hours was relatively high as opposed to an operation utilizing a tractor. In addition, the farmer reported that all but $2 \mathrm{~h}$ of other labor time was spent on the establishment of the practice. Therefore, the $\$ 807.33$ per acre per year represents the cost to establish the riparian buffer strip, as opposed to the cost to maintain it. 
Generally, farms with already established CCBMPs showed a lower cost of utilizing that CCBMP, whereas new installations displayed higher costs per acre for maintenance after establishment was completed. Furthermore, while not statistically significant due to the small sample size, both cover cropping and MIRG tended to show that larger acreages tended to result in lower costs per acre than smaller acreages, with the possible exception of Farm 4.

The average beef and cow dairy MIRG maintenance cost of $\$ 79.82$ per acre, sheep MIRG cost of $\$ 20.02$ per acre, and average cover cropping maintenance cost of $\$ 129.24$ per acre represent an annual budget of labor, fuel, seed, and other input costs necessary for implementing, maintaining, and removing or incorporating CCBMPs on farms already using those practices. The found average cover cropping cost falls within the numbers found in the literature of $\$ 80-\$ 170$ per acre, while MIRG costs were unable to be compared due to methodological differences. MIRG for sheep was also shown to be much lower than cow operations, primarily due to the dramatically lower labor costs resulting from less frequent animal rotations and larger paddocks.

The cost to establish a new MIRG practice (Farm $1-\$ 33.37$ per acre) cover cropped field (Farm 8-\$298.83 per acre), and riparian zone (Farm 11-\$807.33 per acre) demonstrates the logical expectation that establishing a new practice will require addition upfront costs. Furthermore, the first year of maintaining these practices after establishment was shown to be higher than for farms with already established practices. The buffer strip establishment cost also falls within the broad range identified in the literature of $\$ 385-\$ 4,723$. Furthermore, for riparian buffer zones there may be relative yield reductions due to a reduction of land in production if previously in-production land is converted to the riparian buffer strip. This cost was not calculated for this study as it does not fit within the explicit cost of maintenance or establishment costs, but would be calculated on a cost per lost acre basis. The farm studied here did not take any land out of production to establish the riparian buffer.

\section{Cost per Acre Compared to Incentive Program Payments}

This study addressed the research question: What is the cost to install, maintain, remove and/or incorporate CCBMPs in Vermont over the course of one growing season? Results show that the average cost for cover cropping for diversified or vegetable operations is $\$ 129.24$ per acre, MIRG for cow dairy and meat production is $\$ 79.82$ per acre, and a tree based riparian buffer strip cost $\$ 807.33$ per acre in Vermont. While these numbers alone are useful financials for farmers calculating their potential profitability for an upcoming growing season, they can also be compared to incentive program payments to determine if an adequate payment levels are in place to maximize adoption. This is done by comparing our established costs to government WTP levels. Costs shown to be higher than WTP would indicate payments are not high enough to fully compensate farmers for practice use, increasing farm risk through potentially reduced profits. WTP, costs, and WTA levels can then be compared to determine if farmers will, on average, accept established payment levels from incentive programs.

This study found the average cost of cover cropping to be $\$ 129.24$ per acre for farms that had been using cover crops in previous seasons. WTP levels, established through assessment of 2015 EQIP payments [64], were $\$ 79.45$ per acre, and Miller (2014) reported farmer's WTA was \$125.16 per acre. Comparing practice cost to WTP levels, we see that per acre, costs are \$49.79-approximately 
$40 \%$ - higher than WTP levels, indicating payments offered are below the level necessary to maximize farmer adoption by covering practice expenses. Farmer WTA for cover cropping was $\$ 45.71$ higher than existing WTP as well, but $\$ 4.08$ higher than costs. The difference between both the WTA and costs, and WTP levels shows that existing cover cropping payment do not fully cover the costs of implementing the practice.

MIRG costs in this study were found to average \$79.82 per acre, while comparable WTP levels are $\$ 23.91$ per acre. Comparing the two shows that MIRG costs $\$ 55.91$-approximately $70 \%$ - higher than existing WTP levels. Similar to the cover cropping scenario, existing incentive program (EQIP) payments does not adequately compensate farmers for implementing this practice. No studies were found detailing WTA levels for MIRG, so a comparison between WTP, costs, and WTA was not possible.

Furthermore, establishment costs for a riparian buffer strip were found to be $\$ 807.33$ per acre. WTP was $\$ 763.68$, and Miller found WTA to be $\$ 168.33$ for this practice (Table 2). The comparison between costs and WTP for this practice indicates a relatively more adequate payment level, with a difference of $\$ 43.65$ per acre, approximately 5.4\% higher. Here, costs and WTP levels are much higher than WTA levels of farmers. This disconnect likely exists due to variations in riparian buffer strip planting and type characteristics, as demonstrated by the large range in past cost estimates.

Table 2. Comparison of WTA, WTP, and Average Practice Costs.

\begin{tabular}{ccccc}
\hline Practice & WTA $^{\mathbf{1}}$ (\$ per acre) & WTP $\mathbf{( \$ \text { per acre) }}$ & Average Cost $\mathbf{( \$ \text { per acre) }}$ & WTP-Cost (\$ per acre) \\
\hline Cover Crop & 125.16 & $79.45^{*}$ & 129.24 & -9.79 \\
MIRG & N/A & $23.91 * *$ & 79.82 & -55.91 \\
Buffer Strip & 168.33 & $763.68^{* * *}$ & 807.33 & -43.65 \\
\hline
\end{tabular}

Notes. WTP levels are established through assessing EQIP Payments from 2015 (EQIP 2015).* cover cropping practice of HU-Nitrogen Fixing Cover used; ** closest practice to this specific MIRG practice is prescribed grazing, intensive; *** closest practice to this specific buffer planting is tree/shrub establishment, averaged between 110 and 300 per acre; ${ }^{1}$ WTA levels were reported in Miller, 2014.

\section{Conclusions}

\subsection{Implications and Recommendations}

The costs found in this study to install and maintain MIRG, cover cropping, and riparian buffer strips demonstrate to Northeastern and specifically Vermont farmers the unique costs associated with CCBMPs they may be considering adopting. A 2013-2014 study on the effectiveness of various cover crop educational opportunities found that self-experimentation, local workshops, and internet research were the most effective means of learning about new cover cropping methods [45]. Baumgart-Getz, Prokopy, and Floress also found that information and networking variables were useful for predicting best management practice adoption [55]. Therefore, we recommend that local Extension systems incorporate the costs and implementation of CCBMPs into online educational materials and workshops to provide the necessary information to potential practice adopters and generally maximize adoption. Understanding these specifically defined costs will help alleviate farmer perceptions of unknown risks and profitability, two vital barriers to BMP adoption [57-59]. 
CCBMPs like covering cropping and MIRG provide external, public benefits through the mitigating climate change by way of increasing carbon soil sequestration and reducing fossil fuel use. Therefore, under adoption results in agricultural systems contributing to climate change to a greater degree than is necessary. In addition, CCBMPs provide internal benefits that result in more adaptive farms by keeping soil in place, reducing flooding impacts, keeping weeds controlled, managing nutrients, and decreasing imported fertility and feed. Therefore, under-adoption results in a more vulnerable farming population in a changing climate. The costs found in this study should inform policy makers of the true cost of implementing these important practices. Specifically, incentive levels warrant increases for high intensity cover cropping, and high intensity grazing, as the current payment levels are likely resulting in under-adoption given that costs outpace current payment levels by $40 \%-70 \%$. Including the specific internal or external benefits farmers and society receive in this calculation would reduce this difference, as the current calculation is total costs as opposed to net costs (Costs-benefits), and there are certainly numerous benefits associated with each practice. However, given the one year research period for this project, it was not possible to measure specific quantitative on-farm benefits as this would require baseline data from farm operations prior to CCBMP adoption. This would be necessary to allow for differentiation between pre and post farm characteristics.

Large scale adoption of these three CCBMPs may also have unknown implications on the global scale in terms of external benefits. If these practices were to be widely adopted at the regional or national level, and result in general decreased yields, this could result in national crop shortfalls. These shortfalls may then require the import of outside crops, offsetting some of the decreases in emissions and the associated societal benefits. While this issue is outside the scope of this analysis, it is an important consideration when considering national or global adoption of these practices.

Additional specific policy recommendations for increasing MIRG adoption include revenue assurance for farmers who are converting from conventional or confined livestock or dairy operations to MIRG practices over a three or five year period and zero or very low interest loans for conversion costs. While the farms assessed here were not undergoing conversions from one practice to the other, this does represent a notable cost and risk for farmers. Incentive payment programs should also more explicitly incorporate external ecosystem service benefits, such as carbon sequestration, into their payment calculations.

\subsection{Strengths and Limitations}

The primary strength of this study is the data collection method used. With several exceptions, data were collected from each farmer on a daily basis and aggregated to annual costs. When farmers were unable to track on a daily basis using our customized data tracking logs, other existing daily or weekly record keeping materials used by the farmers were relocated to our tracking method. This yielded an accurate picture of inputs, fuel, and labor required for each documented practice over the course of one season.

The costs documented in this study represent the cost to establish and/or maintain CCBMPs. It should be noted that these costs are not intended to reflect the total cost of producing dairy, meat, or vegetable crops; additional feed, veterinary services, regulatory testing, land rent, and other business expenses were not included. This approach was logical for this study as we were interested in the cost 
of specific practices within larger production systems, as opposed to the total end cost for products themselves. Similar to cover cropping being a select practice within vegetable operations, the utilization of MIRG is only part of the broader process of raising livestock. Specific to MIRG, the focus of the reporting is \$/acre instead of a more traditional \$/animal. As a result, dollars per acre found for MIRG practices are difficult to compare to existing studies on MIRG that follow a traditional production system enterprise budget approach. In addition, this study did not incorporate potential increases or decreases in yield resulting from incorporation of these best practices. If practice adoption were to increase profits to a notable degree, the gap between costs and WTP levels may be less importance for farmer adoption.

An additional limitation of our study was the comparability between farms for the different CCBMPs. The farms we worked with offer a picture of Vermont agriculture, that which includes a variety of operations that utilize differing practices. For example, our researched farms plant different mixes of cover crop seeds that cost different amounts, reducing the direct cost comparability between farms. However, the process of averaging these inherently variable costs produces a useful average cost for each practice, except in the case of riparian buffer strips and sheep MIRG. Results of this study showed a relatively narrow range of practice costs for MIRG and cover cropping when the logical outliers were excluded as described previously, indicating established costs are likely relevant to other similar farms within Vermont. However, caution should be taken when generalizing these results, as twelve farms does represent a small sample size. This is especially true in regard to the sheep farm MIRG practice and riparian buffer zone practice, as each had only one sample to draw conclusions from.

\subsection{Future Research}

Future research should establish costs associated with additional CCBMPs, as well as verifying the costs found here for other areas of the Northeastern United States. Specifically, no-till land management practices and stormwater management practices should be prioritized. WTA levels should also be assessed for stormwater management system practices and MIRG. Additionally, further research should be conducted on the adequacy of CCBMP incentive payment levels by comparing WTA and WTP levels once established.

This study does not include the comparative calculated benefits of these CCBMPs. The 12 participating farmers qualitatively discussed why they were using these practices, and anecdotally provided their perceptions of the public and private benefits of each. However, the associated internal and external benefits of these practices were not incorporated in this study given the one year scope of research. It would not have been possible to establish baselines prior to CCBMP establishment. However, future research should work with farms to measure the private benefits before and after practice establishment, while also measuring $\mathrm{GhG}$ emissions to demonstrate public benefits. Specifically, research on private benefits should include potential profit changes from practice adoption. Increases in farmer profits from CCBMP practice adoption would demonstrate a win-win situation for farmers as they would not only receive payments through programs like EQIP, but they would generate better economic returns independent from incentive programs. Potential situations like this would be important inclusions in extension service advisory services provided to farmers. 
In addition, the long vs. short term impacts to carbon sequestration of these practices may be somewhat variable, resulting in fluctuating public benefits. For example, while there would be benefits to short-term carbon sequestration from utilizing cover cropping, if these practices were removed in the future, sequestered carbon would potentially return to the atmosphere. Future research should look into the timescale issue of various CCBMP's impact on carbon sequestration if practices are either continued or removed.

\section{Acknowledgments}

This work was part of the Vermont Agricultural Resilience in a Changing Climate (VARCC) initiative, part of the Agroecology and Rural Livelihoods (ARL) Group. Funding was provided by the University of Vermont's Food Systems Transdisciplinary Research Initiative Additionally, thank you to the twelve farmers that painstakingly tracked data over an entire season. This study would not have been possible without the financial and administrative support supplied by the VARCC and ARL, and the data collection the farmers undertook.

\section{Author Contributions}

Alexander Helling designed and administered the research study along with analyzing the data. David Conner designed and administered the study and edited multiple drafts of the manuscript. Sarah Heiss and Linda Berlin edited the manuscript.

\section{Conflicts of Interest}

The authors declare no conflict of interest.

\section{References}

1. IPCC. Climate Change 2014: Impacts, Adaptation, and Vulnerability. Part B: Regional Aspects. In Contribution of Working Group II to the Fifth Assessment Report of the Intergovernmental Panel on Climate Change; Barros, V.R., Field, C.B., Dokken, D.J., Mastrandrea, M.D., Mach, K.J., Bilir, T.E.; Chatterjee, M., Ebi, K.L., Estrada, Y.O., Genova, R.C., et al., Eds.; Cambridge University Press: Cambridge, UK; New York, NY, USA, 2014.

2. IPCC. Climate Change 2007: Mitigation of Climate Change. In Contribution of Working Group III to the Fourth Assessment Report of the Intergovernmental Panel on Climate Change; Metz, B., Davidson, O.R., Bosch, P.R., Dave, R., Meyer, L.A., Eds.; Cambridge University Press: Cambridge, UK; New York, NY, USA, 2007.

3. IPCC. Climate Change 2014: Mitigation of Climate Change. In Contribution of Working Group III to the Fifth Assessment Report of the Intergovernmental Panel on Climate Change; Edenhofer, O., Pichs-Madruga, R., Sokona, Y., Farahani, E., Kadner, S., Seyboth, K., Adler, A., Baum, I., Brunner, S., Eickemeier, P., et al., Eds.; Cambridge University Press: Cambridge, UK; New York, NY, USA, 2014.

4. Kurukulasuriya, P.; Rosenthal, S. Climate Change and Agriculture: A Review of Impacts and Adaptations; World Bank: Washington, DC, USA, 2013. 
5. Malcolm, S.; Marshall, E.; Aillery, M.; Heisey, P.; Livingston, M.; Day-Rubenstein, K. Agricultural Adaptation to a Changing Climate: Economic and Environmental Implications Vary by U.S. Region; ERR-136; U.S. Department of Agriculture, Economic Research Service: Washington, DC, USA, 2012.

6. Rötter, R.; van de Geijn, S.C. Climate change effects on plant growth, crop yield and livestock. Clim. Chang. 1999, 43, 651-681.

7. Wheeler, T.; Reynolds, C. Predicting the risks from climate change to forage and crop production for animal feed. Anim. Front. 2013, 3, 36-41, doi:10.2527/af.2013-0006.

8. Adams, R.; Fleming, R.; Chang, C.; McCarl, B.; Rosenzweig, C. A reassessment of the economic effects of global climate change on U.S. agriculture. Clim. Chang. 1995, 30, 147-167.

9. Adams, R.M.; Hurd, B.; Lenhart, S.; Leary, N. Effects of global climate change on agriculture: An interpretative review. Clim. Res. 1998, 11, 19-30.

10. Melillo, J.M.; Richmond, T.C.; Yohe, G.W. Climate Change Impacts in the United States: The Third National Climate Assessment; US Global Change Research Program: Washington, DC, USA, 2014; p. 841.

11. Pruski, F.F.; Nearing, M.A. Climate-induced changes in erosion during the 21 st century for eight U.S. locations. Water Resour. Res. 2002, 38, 34.

12. Cure J.D.; Acock B. Crop responses to carbon dioxide doubling: A literature survey. Agric. For. Meteorol. 1986, 38, 127-145.

13. Sardans, J.; Peñuelas, J. The role of plants in the effects of global change on nutrient availability and stoichiometry in the plant-soil system. Plant Physiol. 2012, 160, 1741-1761.

14. Booker, F.; Muntifering, R.; McGrath, M.; Burkey, K.; Decoteau, D.; Fiscus, E.; Manning, W.; Krupa, S.; Chappelka, A.; Grantz, D. The ozone component of global change: Potential effects on agricultural and horticultural plant yield, product quality and interactions with invasive species. J. Integr. Plant Biol. 2009, 51, 337-351.

15. Long, S.P.; Ainsworth, E.A.; Leakey, A.D.B.; Nösberger, J.; Ort, D.R. Food for thought: Lower-Than-Expected crop yield stimulation with rising $\mathrm{CO}_{2}$ concentrations. Science 2006, 312, 1918-1921.

16. Ruiz-Vera, U.M.; Siebers, M.; Gray, S.B.; Drag, D.W.; Rosenthal, D.M.; Kimball, B.A.; Bernacchi, C.J. Global warming can negate the expected $\mathrm{CO}_{2}$ stimulation in photosynthesis and productivity for soybean grown in the Midwestern United States. Plant Physiol. 2013, 162, 410-423.

17. Mader, T.L. Impact of environmental stress on feedlot cattle. West. Sect. Am. Soc. Anim. Sci. 2012, 62, 335-339.

18. Hayhoe, K.; Wake, C.P.; Huntington, T.G.; Luo, L.; Schwartz, M.D.; Sheffield, J.; Wolfe, D. Past and future changes in climate and hydrological indicators in the US Northeast. Clim. Dyn. 2007, 28, 381-407.

19. Ziska, L.H. Changes in competitive ability between a $\mathrm{C}_{4}$ crop and a $\mathrm{C}_{3}$ weed with elevated carbon dioxide. Weed Sci. 2001, 49, 622-627. 
20. Chase, L.E. Climate change impacts on dairy cattle. Fact sheet, Climate Change and Agriculture: Promoting Practical and Profitable Responses. Available online: http://dbccc.onep.go.th/ climate/attachments/article/105/Climate\%20Change\%20Impacts\%20on\%20Dairy\%20Cattle.pdf (accessed on 3 February 2015).

21. Gaughan, J.; Lacetera, N.; Valtorta, S.E.; Khalifa, H.H.; Hahn, L.; Mader, T. Ch. 7: Response of domestic animals to climate challenges. In Biometeorology for Adaptation to Climate Variability and Change; Ebi, K.L., Burton, I., McGregor, G.R., Eds.; Springer: Dordrecht, The Netherlands, 2009; Volume 1, pp. 131-170.

22. Calzadilla, A.; Rehdanz, K.; Betts, R.; Falloon, P.; Wiltshire, A.; Tol, R.J. Climate change impacts on global agriculture. Clim. Chang. 2013, 120, 357-374.

23. Fisher, A.C.; Hanemann, W.M.; Roberts, M.J.; Schlenker, W. The economic impacts of climate change: Evidence from agricultural output and random fluctuations in weather: Comment. Am. Econ. Rev. 2012, 102, 3749-3760.

24. Bradley, B.A.; Wilcove, D.S.; Oppenheimer, M. Climate change increases risk of plant invasion in the Eastern United States. Biol. Invasions 2010, 12, 1855-1872.

25. Saint Michael's College. The Weather and Climate of Vermont. Available online: http://academics.smcvt.edu/vtgeographic/textbook/weather/weather_and_climate_of_vermont.htm \#climate (accessed on 11 August 2015).

26. Vermont Farm Bureau. A Look at Vermont Agriculture. Available online: https://www.agclassroom.org/kids/stats/vermont.pdf (accessed on 12 August 2015).

27. United States Department of Agriculture Census of Agriculture. Census Volume 1, Chapter 2: State Level Data. Table 1. State Summary Highlights: 2012. Available online: http://www.agcensus.usda.gov/Publications/2012/Full_Report/Volume_1,_Chapter_2_US_State_ Level/st99_2_001_001.pdf(accessed on 21 April 2015).

28. Dunnington, G. The Potential Impacts of Climate Change on Agriculture in Vermont. Available online: http:/www.anr.state.vt.us/anr/climatechange/Pubs/VTCCAdaptAgriculture.pdf (accessed on 21 April 2015).

29. Vermont Agency of Natural Resources. Tropical Storm Irene by the Numbers. Available online: http://www.anr.state.vt.us/anr/climatechange/irenebythenumbers.html (accessed on 19 April 2015).

30. Coumou, D.; Rahmstorf, S. A decade of weather extremes. Nat. Clim. Chang. 2012, 2, 491-496.

31. Galford, G.L.; Hoogenboom, A.; Carlson, S.; Ford, S.; Nash, J.; Palchak, E.; Pears, S.; Underwood, K.; Baker, D.V. Our Changing Climate: Considering Vermont's Future in a Changing Climate: The First Vermont Climate Assessment; Gund Institute of Ecological Economics: Burlington, VT, USA, 2014.

32. Smith, P.; Martino, D.; Cai, Z.; Gwary, D.; Janzen, H.; Kumar, P.; McCarl, B.; Ogle, S.; O’Mara, F.; Rice, C.; et al. Greenhouse gas mitigation in agriculture. Philos. Trans. R. Soc. B 2008, 363, 789-813.

33. West, T.O.; Marland, G. A synthesis of carbon sequestration, carbon emissions, and net carbon flux in agriculture: Comparing tillage practices in the United States. Agric. Ecosyst. Environ. 2002, 91, 217-232, doi:10.1016/S0167-8809(01)00233-X.

34. Lal, R. Soil carbon sequestration to mitigate climate change. Geoderma 2004, 123, 1-22. 
35. Council for Agricultural Science and Technology. Preparing US Agricultural for Global Climate Change; Task Force Report; Council for Agricultural Science and Technology: Ames, IA, USA, 1992; p. 119.

36. Smit, B.; Skinner, M.W. Adaptation options in agriculture to climate change: A typology. Mitig. Adapt. Strateg. Glob. Chang. 2002, 7, 85-114, doi:10.1023/A:1015862228270.

37. Schattman, R.; Mendez, E.; Westdijk, K.; Caswell, M.; Conner, D.; Koliba, C.; Darby, H. Vermont agricultural resilience in a changing climate: A transdisciplinary and participatory action research (PAR) process. In Agroecology, Ecosystems and Sustainability. Advances in Agroecology Series; Benkeblia, N., Ed.; CRC Press/Taylor and Francis: Boca Raton, FL, USA, 2015; pp. 325-346.

38. Smit, B.; McNabb, D.; Smithers, J. Agricultural adaptation to climatic variation. Clim. Change 1996, 33, 7-29.

39. Wall, E.; Smit, B. Climate change adaptation in light of sustainable agriculture. J. Sustain. Agric. 2005, 27, 113-123, doi:10.1300/J064v27n01_07.

40. Vermont Natural Resources Conservation Service. Cover Crop. Conservation Practice Standard. Code 340. Available online: http://efotg.sc.egov.usda.gov/references/public/VT/VT340.pdf (accessed on 21 April 2015).

41. Cornell Cooperative Extension. Cover Crops for Vegetable Growers. Available online: http://covercrops.cals.cornell.edu/late-summer-legumes.php (accessed on 21 April 2015).

42. Morton, T.; Bergtold, J.; Price, A. The Economics of Cover Crop Biomass for Corn and Cotton. In Proceedings of the Southern Conservation Systems Conference, Amarillo, TX, USA, 26-28 June 2006.

43. Solano and Yolo County Resource Conservation Districts. Annual Winter Cover Crops. Available online: http://www.yolorcd.org/documents/annual_winter_cover_crops.pdf (accessed on 15 February 2015).

44. Mannering, J.V.; Griffith, D.R.; Johnson, K.D. Winter Cover Crops-Their Value and Management; AY-247; Purdue University Cooperative Extension Service: West Lafayette, IN, USA, 2007.

45. North Central SARE. 2013-2014 Cover Crops Survey Analysis. Available online: http://www.sare.org/Learning-Center/From-the-Field/North-Central-SARE-From-the-Field/201314-Cover-Crops-Survey-Analysis (accessed on 21 April 2015).

46. Miller, J. Farmer Adoption of Best Management Practices Using Incentivized Conservation Programs: Calculating Vermont Farmer WTA Incentive Levels Using Conjoint Analysis. Master's Thesis, The University of Vermont, Burlington, VT, USA, 2014.

47. Hancock, D.; Andrae, J. What is Management-intensive grazing and what can it do for my farm? Available online: http://www.caes.uga.edu/topics/sustainag/grazing/pdf/AnIntroductionto IntensiveGrazing.pdf (accessed on 20 April 2015).

48. Bruce, J.P.; Frome, M.; Haites, E.; Janzen, H.; Lal, R.; Paustian, K. Carbon sequestration in soils. J. Soil Water Conserv. 1999, 54, 382-389.

49. Mariola, M.J.; Stiles, K.E.; Lloyd, S. The social implications of management intensive rotational grazing: An annotated bibliography. Center for Integrated Agricultural Systems, University of Wisconsin- Madison, Madison, WI, USA, 2005. 
50. University of Vermont. Sustaining Small and Medium-sized Farms, Natural Resources, and Rural Communities: The Role of Rotational Grazing. Available online: http://www.uvm.edu/ grazing/ index.php?id=northeast-dairy-farms (accessed on 21 April 2015).

51. Nakao, M.; Brown, L.; Leeds R. The Economics of Vegetative Filter Strips. Ohio State University Extension Factsheet. Available online: http://ohioline.osu.edu/ae-fact/0006.html (accessed on 20 April 2015).

52. Natural Resources Conservation Service. Riparian Forest Buffer, Conservation Practice Job Sheet, 391. Available online: ftp://ftp.wcc.nrcs.usda.gov/wntsc/strmRest/buffers/RiprarianForestBuffer JobSheet.pdf (accessed on 17 September 2015)

53. Lynch, L.; Tjaden, R.L. When a Landowner Adopts a Riparian Buffer-Benefits and Costs. Available online: https:/extension.umd.edu/sites/default/files/_docs/programs/riparianbuffers/ FS774.pdf (accessed on 21 April 2015).

54. Pennsylvania Department of Environmental Protection. Riparian Forest Buffer Guidance. PA PED Online Library. Volume 31, Tab 5. Available online: http://www.elibrary.dep.state.pa.us/ dsweb/Get/Document-82308/394-5600-001.pdf (accessed on 20 April 2015).

55. Baumgart-Getz, A.; Prokopy, L.S.; Floress, K. Why farmers adopt best management practice in the United States: A meta-analysis of the adoption literature. J. Environ. Manag. 2012, 96, 17-25.

56. Knowler, D.; Bradshaw, B. Farmers' adoption of conservation agriculture: A review and synthesis of recent research. Food Policy 2007, 32, 25-48.

57. Cary, J.W.; Wilkinson, R.L. Perceived profitability and farmers' conservation behaviour. J. Agric. Econ. 1997, 48, 13-21.

58. Marra, M.; Pannell, D.J.; Abadi Ghadim, A. The economics of risk, uncertainty and learning in the adoption of new agricultural technologies: Where are we on the learning curve? Agric. Syst. 2003, 75, 215-234.

59. Saltiel, J.; Bauder, J.W.; Palakovich, S. Adoption of sustainable agricultural practices: Diffusion, farm structure, and profitability. Rural Sociol. 1994, 59, 333-349.

60. USDA-NASS. Census of Agriculture. Available online: http://www.agcensus.usda.gov/ (accessed on 14 March 2015).

61. United States Department of Agriculture Economic Research Services (USDA ERS). 2015 Farm Household Income Forecast. Available online: http://www.ers.usda.gov/otpics/farm-economy/ farm-household-well-being/2015-farm-household-income-forecast.aspx (accessed on 11 August 2015).

62. Conner, D. Shortcuts to Measuring Crop Profitability: Are They Misleading? Available online: http://agribusiness.dyson.cornell.edu/SmartMarketing/ (accessed on 19 March 2015).

63. Swinton, S.M.; Lupi, F.; Robertson, G.P.; Hamilton, S.K. Ecosystem services and agriculture: Cultivating agricultural ecosystems for diverse benefits. Spec. Sect.-Ecosyst. Serv. Agric. Ecosyst. Serv. Agric. 2007, 64, 245-252, doi:10.1016/j.ecolecon.2007.09.020. 
64. EQIP. 2015 EQIP Cost List-General. Available online: http://www.nrcs.usda.gov/wps/ portal/nrcs/main/nc/programs/financial/eqip/ (accessed on 20 April 2015).

(C) 2015 by the authors; licensee MDPI, Basel, Switzerland. This article is an open access article distributed under the terms and conditions of the Creative Commons Attribution license (http://creativecommons.org/licenses/by/4.0/). 